IFN Working Paper No. 1047, 2014

Retail Productivity: Investigating the Influence of Market Size and Regional Hierarchy

Özge Öner 


\title{
RETAIL PRODUCTIVITY
}

\section{Investigating the influence of market size and regional hierarchy}

\author{
Özge Önera, b
}

\begin{abstract}
This paper investigates the determinants of the productivity of independent retail stores in Sweden by focusing on the impact of market size and regional hierarchy while controlling for several store and employee characteristics over time. The analysis utilizes Swedish store-level data for the years 2002-2008. To capture the urban-periphery interaction in retail markets, the analysis (i) uses an accessible market potential measure, which captures the impact of the potential demand both in close proximity in the region, and from outside the region separately, and (ii) investigates the stores that are located in central and non-central markets respectively. The results show an approximately 10 percent higher productivity premium associated with the market size in close proximity for centrally located independent stores, whereas regional market size is found to play an equally important role for both stores located in central markets and stores located in peripheral markets. The findings also show that employee characteristics do not contribute to the productivity of stores in central markets but that small but significant productivity returns are captured for stores located in peripheral markets. The differences in the impact arising from the market potential measures highlight the importance of taking the spatial continuum and regional hierarchy into account in an examination of the market size-productivity relationship for retailers.
\end{abstract}

Keywords: Retail, Productivity, Urban rural hierarchy, Market accessibility

JEL codes: R11, R12, L81, D24

The author wish to thank Handelns Utvecklingsråd (The Swedish Retail and Wholesale Development Council), and the Jan Wallander and Tom Hedelius Foundation for financial support.

a Research Institute of Industrial Economics (IFN), P.O. Box 55665, SE-10215 Stockholm, Sweden

b Centre for Entrepreneurship and Spatial Economics, Jönköping International Business School, Gjuterigatan 5 Building B, SE-55111, Jönköping, Sweden

E-mail: ozge.oner@ifn.se 


\section{Introduction}

This paper examines the relevance of market size and regional hierarchy for retailers' productivity. Retailing constitutes a large share of the overall economy in almost all of the countries in the world. Moreover, retailing also serves the purpose of an important urban amenity and contributes to a location's attractiveness by providing consumption possibilities (Glaeser et al., 2001). Yet, empirical research on the sector as a whole that accounts for the interactions among several marketplaces is limited. Research on various aspects of retail location is mostly limited to case studies and limited geographical units. In addition, although the consensus in the literature is that retailing is heavily dependent on proximity to sufficiently large demand, the relevance of the spatial continuum and urban-periphery interaction is often neglected in research on the importance of market size for the performance of retailer performance. From a regional economics perspective, we know that the demand inflow to a location plays an important role in the presence and scale of retail clusters. The importance of external demand for retailers attenuates with increasing distance (Haynes and Fotheringham, 1984; Larsson and Öner, 2014). For several decades, gravitational approaches to estimating retail market boundaries have suggested that larger markets attract higher demand (Reilly, 1929; Converse, 1949; Huff, 1964). However, the demand inflow to a market is dependent on not only the market's size but also its place in the regional hierarchy. Thus, not only the size of the market but also the market's place in a hierarchical order in the system of regional markets is important for the retail sector. Traditional location theories suggest that demand flows from peripheral (non-central) markets toward the central market in the same region, but usually not the other way around (Haig, 1927; Christaller, 1933; Lösch, 1940). In this strand of literature, it is argued that the importance of demand for retailers cannot be limited to very proximate markets (Lakshmanan and Hansen, 1965; Beckmann, 1958; 1999). Ignoring these fundamental aspects of location theories in empirical exercises on retail productivity may result in overestimation of the importance of the demand in close proximity and underestimation of the relevance of the demand at greater distances.

The spatial aspects of retail markets are particularly important for independent stores that do not belong to a chain, as their survival is solely dependent on their own performance in a particular market. We have observed the retail landscape transform tremendously as chain stores have thrived all around the world over the past half-century. Researchers and policy makers have been alarmed by the decline of small and independently owned stores. Today, chain stores hold a competitive advantage by offering lower prices and a larger variety of goods because of scale economies and technological advances (e.g., more efficient distribution channels, online retailing). This trend instigated the ongoing debate on the survival of independent stores and the attractiveness of downtown retailing, which is an acknowledged asset for urban vitality (Glaeser et al. 2001). Despite the challenges, the majority of the retail sector still consists of independently owned stores and their importance for the economic and social milieu is undeniable ${ }^{1}$.

\footnotetext{
1 In terms of the number of stores, approximately 60 percent of the Swedish retail market is dominated by independently owned stores.
} 
This paper aims to elucidate (i) the importance of market size and (ii) the relevance of a market's place in the regional hierarchy for independent retailers' productivity. In the course of examining the market sizeproductivity relationship for independent retailers, the analysis also captures the importance of store and employee attributes for productivity. In addition, the paper extends research on the returns to market size and place in a regional hierarchy for independent retailers of different types and sizes.

In broad strokes, this paper positions itself within a market size-productivity framework, and the issue of returns to market scale is discussed from different angles. However, the contribution of the analysis is that it specifically addresses an economic activity that is heavily dependent on proximity to sufficient size of demand. What makes the retail sector especially suitable for the framework of this analysis is the strong influence of market size and proximity to potential demand. This strong dependence arises because the consumption of retail goods occurs either at locations where retail services are provided or in very close proximity to point of sale. Therefore, any reallocation of individuals and households between regions would be expected to influence the geography of the retail sector and the productivity of its actors. Stores located in large markets or in close proximity to them enjoy not only a larger number of consumers but also the benefits that arise from different forms of agglomeration economies.

The productivity returns to market scale are multilayered. Scale economies can be external to the retailers that are located in a large marketplace (e.g., knowledge spillovers, shared infrastructure and services, and a large pool of labor) (Puga, 2010; Hanson, 2001). However, sufficiently large demand in close proximity may also allow these retailers to exploit the productivity benefits that arise from internal scale economies. Because these retailers can operate at a larger scale, they can reduce their relative cost per sale, and such reduced costs would be reflected in their productivity. This interdependent aspect of economies of scale makes it challenging to identify the portion of the productivity benefits that can be attributed to the external or internal scale. However, in the specific case of independent retailers in the Swedish market, no obvious relationship exists between the scale of markets and the internal scale of stores ${ }^{2}$. In other words, large independent stores are not necessarily sorted into large markets. Thus, a distinction must be drawn between the 'size' of demand and the 'nature' of demand in large markets. For the relationship between the market scale and the productivity of independent retailers, I argue that the nature of the demand in large markets allows independent retailers to specialize in niche goods and services and thus to exploit the demand from a certain segment of consumers. In that sense, the diversity and scale of demand may allow these independent retailers to charge higher prices for the specialized goods and services they provide, which would not be feasible or profitable to provide in smaller markets simply because of insufficient demand. Therefore, the extent of the demand in large and central markets should be reflected in the productivity of retailers, and this impact should vary with respect to the type of retailing in question.

2 The data used for the empirical analysis show that the correlation between the market size in close proximity and the store size in terms of the number of employees is sometimes as low as 0.04 . 
In addition to being one of few empirical attempts to identify the returns to market scale for retail, this paper contributes to the existing literature by (i) accounting for the spatial continuum with the use of accessible market size measures, and by (ii) highlighting the variation in productivity across central and peripheral retail markets. The results of the analysis show that the immediate market (the municipal market size) is more important for independent stores' productivity in central markets, whereas the regional market potential appears to have an equally large impact on both stores in central markets and stores in peripheral markets. The findings suggest that employee characteristics are important only for stores located in peripheral markets. After market size and store characteristics are controlled for, physical capital appears to have the same impact on productivity regardless of the centrality of the market, whereas the size of the store in terms of the number of employees plays a slightly more important role in the productivity of the stores located in non-central markets than in the productivity of the stores located in central markets.

The paper continues by providing background material and the research motivation, which is followed by the calculation of the accessible market size measures that are used in the empirical analysis. Then, the empirical section outlines identification issues and explains the data and variables, and the paper concludes with a discussion of the results.

\section{Background and motivation}

Retailers specialize in providing goods and services that are demanded by consumers and producers, such as a range of goods, convenience shopping, customer services, and packing and credit facilities (Johnston et al., 2000). The most distinct characteristic of retailing as an economic activity is probably its strong dependence on location. Owing to the nature of the transactions carried out in retail establishments, one is likely to find these establishments in (or close to) the centers of cities or regions. One concrete explanation for this phenomenon is that the transactions in the retailing sector often require face-to-face interactions between buyers and sellers ${ }^{3}$. Although its importance varies across different types of retailers, high sensitivity to distance to demand is a retail phenomenon ${ }^{4}$.

A large body of literature utilizing traditional location theories addresses the location patterns of retail stores. Classics such as Reilly's (1929) "law of retail gravitation" introduce the idea that the demand flow between retail markets is positively associated with the sizes of the markets and negatively associated with the distance between them. Following this gravitational approach, various researchers have aimed to determine the retail market boundaries (Converse, 1949; Huff, 1964). Based on the "Central Place Theory" framework of Christaller (1933) and Lösch (1940), research on retail location highlights the regional hierarchy between retail markets where the demand for services attenuates with distance from the core to

\footnotetext{
${ }^{3}$ Although we have observed a significant increase in online shopping over the past decade, the retail sector across the world is still dominated by offline stores (Birkin et al., 2002).

${ }^{4}$ For example, in Dicken and Lloyd (1990), the distance to demand is argued to be relatively more important for low-order goods that are meant for frequent purchases (nondurables) than for high-order goods that are meant for less frequent purchases (durables).
} 
the periphery (Berry, 1967; Berry and Garrison, 1958a; 1958b; Applebaum and Green, 1974). From a "within-city variation" point of view, the "Bid Rent Theory" argues that central markets are allocated to the activities that can pay the highest rent (Haig, 1927; Scott, 1970; Johnston, 1973).

Previous empirical research has shown that shoppers do not always patronize the nearest center where they can find a particular good or service (Golledge et al., 1966; Clark, 1968). Multipurpose shopping trips are found to motivate customers to travel to a range of locations, depending on the goods or services that they are seeking (O’Kelly, 1981, 1983; Thill and Thomas, 1987; Johnston and Rimmer, 1967; Craig, Ghosh and McLafferty, 1984). For example, combined with the convenience of high accessibility and parking facilities, regional malls illustrate how multipurpose shopping motivates people to travel greater distances even if closer options are available. Along this line of thinking, stores that are clustered in large and central marketplaces should also benefit from the possibility of attracting multipurpose shoppers from farther distances owing to the breadth and depth of the retail services that are offered in the market. Consumers' multipurpose shopping behavior is also argued to be one of the reasons why retailers cluster in space (Parr and Denike, (1970b)). The argument is that consumers are motivated to engage in multipurpose shopping trips so that they can reduce their overall transport and time costs by shopping for a bundle of goods at once in order to make the purchase of a single item less costly. Thus, being located in a diverse retail cluster would allow retailers to exploit the local demand to a greater extent. Similarly, the new economic geography (NEG) literature refers to this type of agglomerative force as the "love-of-variety" effect (Krugman, 1991; Fujita et al., 1999; Fujita \& Thisse, 2002). The argument is that larger marketplaces are more competent at providing greater variety (see, e.g., Andersson \& Klaesson, 2009).

Figure 1 displays the process through which the benefits from market size can be realized by stores. When we try to understand the mechanism through which firms in general benefit from market size, we need to distinguish between the demand and supply sides. When firms in general and stores in particular optimize their location, they rely heavily on the potential demand within close proximity, as proposed by location theories. High potential demand secures the survival of a shop and can allow a retailer to offer customer services with high fixed costs that would be too costly to cover in a smaller market. Even when we assume that the prices of products are constant across space, the number of transactions per employee in a store is likely to be higher in denser and larger markets. From a multipurpose shopping trip perspective, a larger and more accessible market with greater variety should also imply greater demand for a retailer, as the market for the particular retailer would be an attractive market for customers to patronize (Johnston and Rimmer, 1967; Craig, Ghosh and McLafferty, 1984). In markets where we observe higher degrees of colocation between different types of retailers, we would see an even greater inflow of demand.

For shops, being closer to demand implies being close to other shops. This demand-driven location choice of stores (and other firms) results in clustering in space, which generates agglomerative forces. These forces enter into firms' location choice, which feeds back the process. 


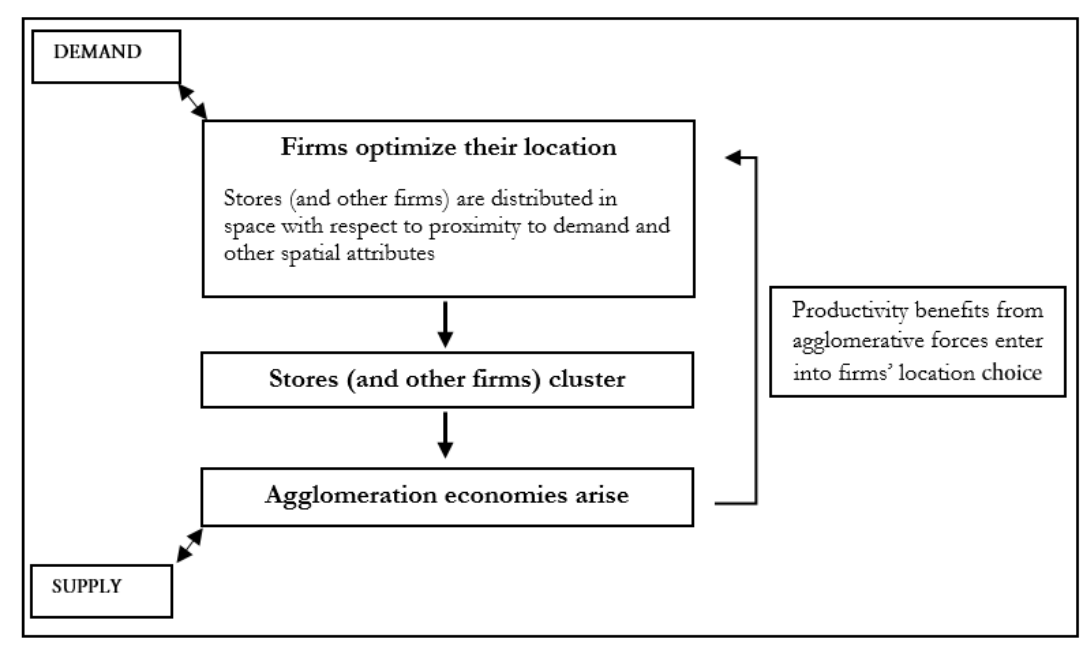

Figure 1: Returns to market size for retailers

Economic actors, firms, and individuals are found to perform better in dense and agglomerated places. The proposition that density is positively associated with both the productivity of individuals and the entities in which individuals create economic value (together with other forms of production factors) is not a recent one. Over two centuries ago, Adam Smith (1776) had already acknowledged the relative importance of the internal scale for production, whereas a century ago Marshall (1890) deliberately discussed those positive externalities that result from the scale of the market. However, when we examine the literature aiming to quantify the impact of the market scale on productivity levels, we see rapid development only over the past few decades (Puga, 2010).

Numerous scholars have addressed the causes of agglomeration economies and the positive externalities associated with geographical concentration. For example, Ohlin (1933) considers four determining factors for agglomeration to arise: (i) internal scale economies, (ii) localization economies, (iii) urbanization economies, and (iv) inter-industry linkages (input-output circulation). Regarding internal scale economies, the potential size of the demand in a market is directly related to the fixed costs of a firm (both material and nonmaterial); accordingly, in a larger market, a firm can operate at a larger scale and, ergo, enjoy a productivity increase as its output increases (Krugman, 1990, 1991; Johansson and Karlsson, 2001).

In a nutshell, agglomerative forces provide more efficient facility and supplier sharing, greater individual specialization, a larger labor pool, and hence better labor-matching opportunities, which combine to induce more productive processes. Accordingly, Duranton and Puga (2004) identify the three main micro foundations of agglomeration economies as sharing, matching, and learning. Sharing refers to a common infrastructure (Scotchmer, 2002), a larger pool of labor (Marshall, 1890; Ellison et al., 2010), and intermediaries and input suppliers (Abdel-Rahman and Fujita, 1990; Rosenthal and Strange, 2001). Matching refers to the average quality of matching between employers and employees, as well as between buyers and suppliers (Helsley and Strange, 1990; Coles and Smith, 1998; Costa and Kahn, 2000). Finally, cities also facilitate knowledge spillovers via learning (Glaeser, 1999; Rosenthal and Strange, 2003; Glaeser 
and Maré, 2001; Duranton and Puga, 2001; Larsson, 2014), and the diverse nature of cities permits higher levels of creativity and productive interactions between individuals (Jacobs, 1969).

The majority of the advantages associated with agglomerative forces are relevant to retailers. However, retailing has distinct aspects that can benefit from the market scale. The individuals working in the sector have greater incentives to increase their performance to enjoy sale-based bonuses. Any two individuals with similar job definitions in the same type of retailing activity would still be engaged in different sets of tasks in markets of different sizes. Thus, individuals tend to be more productive in denser marketplaces, as retailers and their employees in denser marketplaces need to engage in more complex tasks and intensive interactions.

Owing to the nature of the demand in denser and larger markets, retailers can specialize in either one or a few goods and services, become niche companies, and charge more for the premium service that they provide. Stores located in larger markets can benefit from the possibility of spreading the cost of providing additional services and in-store elements and can thus differentiate themselves in the market. Only a retailer in a sufficiently large market can serve enough customers to achieve an optimum match with a specific segment of consumers. Thus, the majority of niche stores are located in larger and central markets, and specialized stores generally perform better in places with a variety of consumers, just as consumers generally prefer places with a variety of retailers. Accordingly, in many small and peripheral markets, we do not see a full spectrum of retail services; indeed, some retail branches do not even exist in very small markets 5 .

This paper does not seek to differentiate between the impact of traditional agglomerative forces that arise from the scale of the market and that of agglomerative forces that are exclusive to the retail sector. I acknowledge that the relation between the scale of the market and firms' productivity may vary. A significant share of the impact of market size for retailers may be driven by the traditional aspects of agglomeration. The specific benefits that retailers derive from the size of the market are not within the scope of this study but should be addressed by future research.

\section{The accessible market size and the Swedish retail market}

The measurement and use of market potential in the analysis in this paper constitute the foundation for the paper's contribution to the literature: the market potential measure allows for the observation of not only size effects but also the interaction between urban and peripheral retail markets. Indeed, this measure captures the benefits associated with the scale of a place (e.g., better infrastructure, higher place attractiveness, and higher connectivity). Many regions consist of one or several central marketplaces

\footnotetext{
${ }^{5}$ Christaller (1933) defines the distance to this boundary as the "real range" of a good, and he terms the minimum bound on the range of a good as the "lower limit". In the work of Denike and Parr (1970a), this lower limit is defined as the "threshold range": "Given the equilibrium market price, the threshold range represents the distance to the perimeter of an area enclosing a minimum level of aggregate demand, which is sufficient to permit the commercial supply of the good, i.e., which permits only normal profits to be earned" (p. 570).
} 
surrounded by smaller peripheral markets. Central markets are expected to play a more influential role in the supply of consumer services, as well as in many other economic activities that require intensive interactions between economic actors. By contrast, individuals from peripheral markets can be expected to commute to the core market to consume the goods that are available in the center. This paper uses a central versus non-central municipality division for Swedish regions. Central and non-central municipalities in the Swedish context are based on integrated spatial labor markets. Municipalities that are integrated in terms of commuting constitute a functional region, which also corresponds to a local labor market. There are 81 local labor markets in Sweden, with one central municipality at the core of each. Thus, the economic interaction within a region is more intensive than it is across regions (Klaesson et al., 2014). One of the advantages of using Swedish data is the monocentric nature of Swedish regions, which allows for a coherent investigation of the urban-periphery interaction.

Market potential is a measure of the magnitude of the economic concentration and network opportunities both within and between regions (Lakshmanan and Hansen, 1965). Johansson and Klaesson (2007) shed light on the ways to distinguish between the internal and external market potentials of functional regions, as different types of goods and services have different levels of interaction intensity, i.e., different levels of intensity in the interactions between buyers and sellers. Johansson and Karlsson (2001) also mention that interaction-sensitive goods and services have distance-sensitive transaction costs that rise sharply when these transactions take place between regions rather than within regions.

This study uses each Swedish municipality's accessibility to wage sums as a proxy for the total demand in that region. The calculations are based on the earlier work of Johansson, Klaesson, and Olsson (2002), which is further developed in Johansson and Klaesson (2011), where they investigate the agglomeration dynamics of business services. The total market accessibility of each municipality is divided into three parts as follows:

$S_{a}^{t o t}=S_{a}^{M}+S_{a}^{R}+S_{a}^{E}$

In equation $1, S$ denotes the size of the market, and $S_{a}^{M}$ denotes the intra-municipal market size, $S_{a}^{R}$ represents the intra-regional market size, and $S_{a}^{E}$ is the extra-regional market accessibility for a given municipal market, $a$. What is meant by "intra-regional" in this context is the accessibility of one municipality to other municipalities within the same local labor market region.

In the present context the sum of the three components in the equation above is probably not the appropriate market potential measure. For a specific municipal market it gives the overall market potential without consideration about the origin of purchasing power. The expression makes it impossible to 
distinguish between possible competition effects between municipalities for consumers located in different municipalities within the same labor market area and different labor market areas. In order to accomplish that we need to allow for the possibility for the three components to have separate effects. The basic argument is that the influence of the three components in the equation may differ for different municipalities. Let $N=\{1, \ldots, \mathrm{n}\}$ be a set containing all municipalities in the economy, and let $R$ denote a subset defining a local labor market area containing several municipalities within $N$. Then let $a$ be an individual municipality contained in $R$. Then we can define $R-a=R \backslash$ a to denote the municipalities in region $R$ excluding the individual municipality $a$. Also, let $N-R=N \backslash \mathrm{R}$ denote all the municipalities in the economy excluding the ones in $R$. Using these definitions, I define the three parts of the total accessibility as follows:

$\begin{array}{ll}\text { Municipal market size: } & S_{a}^{M}=W_{a} e^{\left\{-\lambda_{M} t_{a a}\right\}} \\ \text { Regional market size: } & S_{a}^{R}=\sum_{R-a} W_{R} e^{\left\{-\lambda_{R} t_{a R}\right\}} \\ \text { External market size: } & S_{a}^{E}=\sum_{N-R} W_{N} e^{\left\{-\lambda_{N} t_{R N}\right\}}\end{array}$

$W$ in the formula denotes the wage sums in a given municipality, $a$. The travel time by car between two given municipalities is represented by $t$, and $\lambda$ is used as a time-distance decay parameter. For each geographic aggregation level, $\lambda$ takes a different value 6 . The values are calculated following the calculations of Johansson et al. (2002) with Swedish commuting data.

Utilizing the distance decay is an efficient way to control for spatial dependencies as well as a superior way to capture the actual scale impact because this measure allows us to account for a spatial continuum (Andersson and Gråsjö, 2009). The figure below represents the three components of the market potential measure, where $a$ is a municipality located in a region, $R$, which is contained in the greater Swedish market, $N$. Using the time distances in combination with the distance decay parameter and wage sums gives us a unique total market potential value for each municipality in the economy, as explained above.

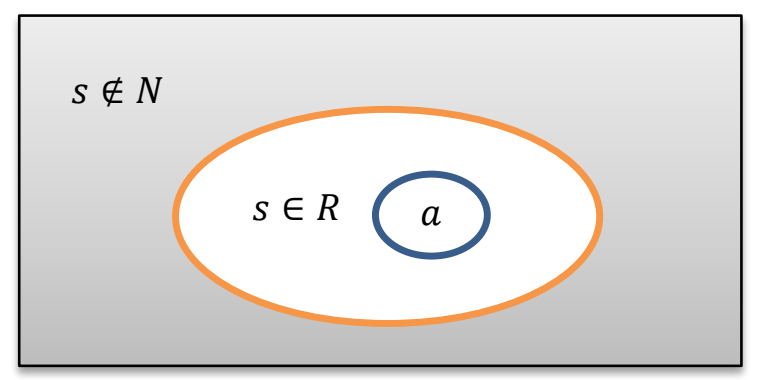

Figure 2: Market potential divided into three parts

${ }^{6} \lambda_{a M}($ municipal $)=0.02, \lambda_{a R}($ regional $)=0.1$, and $\lambda_{a N}($ external $)=0.05$ 

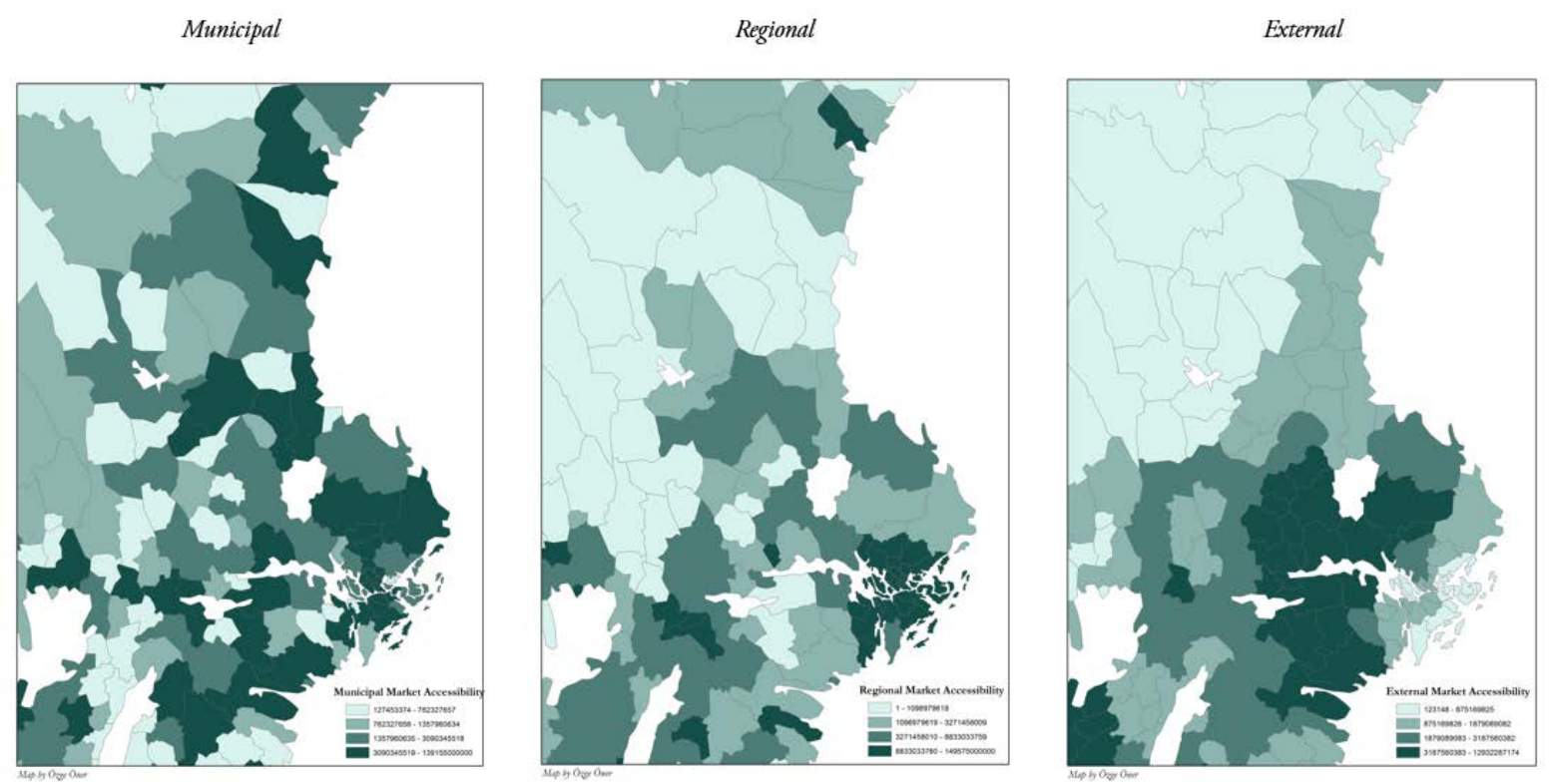

Figure 3: Accessible market size measures for Swedish municipalities: Municipal, Regional, and External

In Figure 3, I show three maps for the three accessible market size measures for the Stockholm region and the surrounding municipalities to provide a visual overview. The municipal market size is much more dispersed than the regional and external market sizes. The first map shows the market size in the immediate surroundings, whereas the second map indicates the regional market size that is relevant for a municipality. Finally, the last map shows the market potential that extends beyond the region in which a municipality is located.

The municipal market size should be important for both centrally and peripherally located retailers. However, with the regional market size, peripherally located retailers should be more sensitive than the centrally located retailers because their own domestic market is limited.

Another aspect of a market's place in the regional hierarchy relates to specialization. One way to capture the relative importance of specialization in retail is to examine the degree of concentration of the sector with respect to other economic activities. A market may be relatively small in size but still exhibit a considerable degree of concentration in a given sector with respect to other local economic activities. Location quotients (LQs) are a simple but straightforward way to capture the relative importance of a sector in a geographically delimited area. Figure 4 shows a Swedish map where the municipalities are 
shaded according to the LQ values ${ }^{7}$ for the retail sector. Municipalities that are colored red have a LQ higher than 1, which implies that retailing is one of the basic (exporting) sectors in these municipalities.

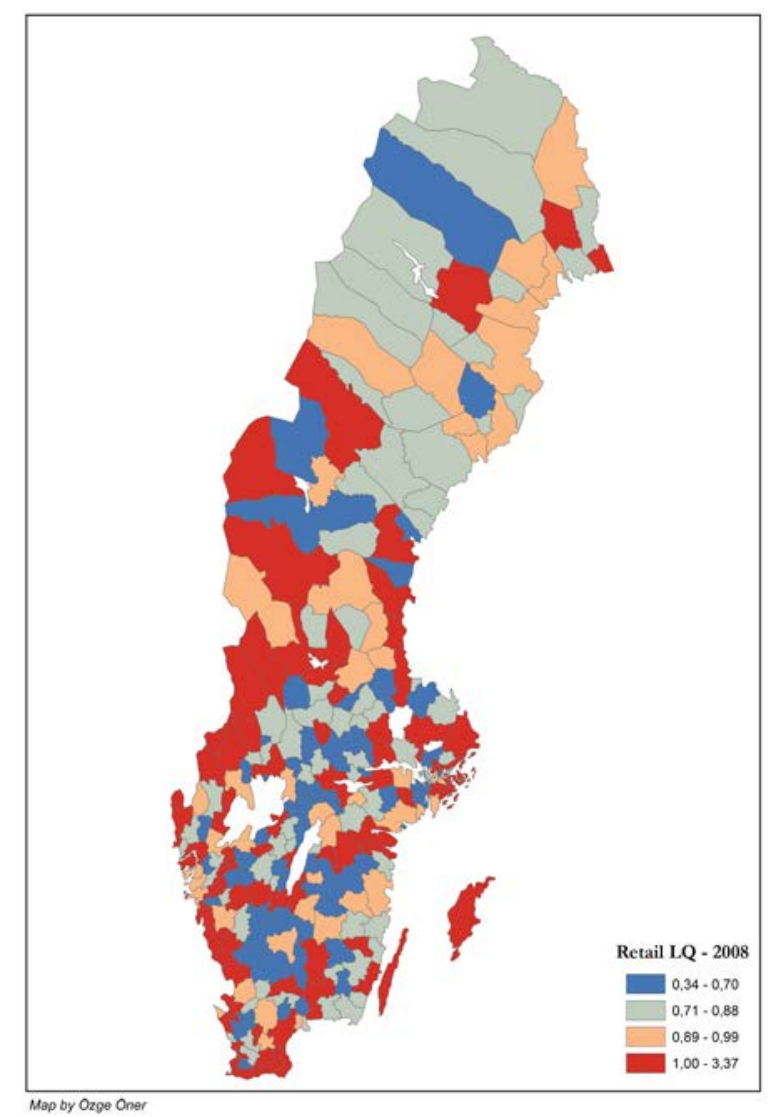

Figure 4: Retail location quotients for the entire Swedish market

The LQ map presented above reveals that municipalities with a high LQ value are more dispersed across space than what we previously found in the accessibility maps. Because the retail concentration does not depend on the size of the market, we see a LQ greater than one in municipalities that do not necessarily have a large market. The concentration of retail activities across large municipalities and metropolitan regions is generally predictable. In addition to showing this predictable concentration, the LQ map allows us to observe the concentration of retail activities along the Norwegian border and thus to find that the demand is not driven domestically alone. Municipalities such as Strömstad, Årjäng, and Eda are known to attract consumers from Norway owing to the lower prices for goods and services in Sweden. Moreover, places such as Åre and Härjedalen are popular destinations for winter sports, and the concentration of retail activities in these locations signals that the demand for retail is not exclusive to domestic consumers.

\footnotetext{
${ }^{7}$ The LQs used in the map are calculated for the data from 2008.

The calculation of the LQ is as follows: $\left(\mathrm{E}_{\mathrm{r}, \mathrm{i}} / \mathrm{E}_{\mathrm{i}}\right) /\left(\mathrm{E}_{\mathrm{r}} / \mathrm{E}\right)$,

where $\mathrm{E}$ is the total employment in the country and $\mathrm{E}_{\mathrm{i}}$ is the total employment in region $\mathrm{i}$. Additionally, $\mathrm{E}_{\mathrm{r}, \mathrm{i}}$ denotes the employment in the retail sector in region $\mathrm{i}$, and $\mathrm{E}_{\mathrm{r}}$ denotes the total employment in retailing.
} 
As with economic activity, in general, the gross retail employment is clustered in the southern part of the country. Nevertheless, large marketplaces in the north still exhibit a considerable level of relative retail concentration. These marketplaces are more likely to be supported by the external market, given the degree of retail concentration in the surrounding municipalities. Once again, a higher LQ for a municipality does not always imply a large retail market in absolute terms. Although we find various regions to be competitive in retailing in relative terms, the Malmö, Stockholm, and Gothenburg regions together account for approximately 40 percent of the overall retail employment in the entire country.

\section{Empirical design}

\subsection{Identification}

In simple terms, productivity can be defined as the ratio of outputs to inputs, which reflects an average measure of the efficiency of production. The retail literature has been very contentious owing to the debate on the appropriateness of different types of productivity measures ever since the first empirical application by Hall, Knapp, and Winsten (1961). A considerable amount of research is devoted to the discussion of what type of productivity measures can be used in an empirical setting ${ }^{8}$. To operationalize a production function for retailing, previous research has used different alternatives for an output measure (Bucklin, 1980; Lusch and Ingene, 1979). The consensus is that value added is the best measure of retail output (Doutt, 1984; Ingene, 1984; Ratchford and Brown, 1985). Lusch and Ingene (1979) argue that value added has the "highest predictive validity" in OLS estimations as an output measure for retailing. Among different types of retailing activities, the input structure can be drastically different. However, the labor used in the production process is a relatively straightforward production factor that can serve as a proxy for input factors across multiple branches of a sector in a consistent manner. Thus, this paper adopts the value added per employee as a retail productivity measure (Reynolds et al., 2005).

The conventional way to describe the production process is to use a Cobb-Douglas production function, in which the weighted output is the product of labor, capital, and total factor productivity9. The estimation performed in this paper is of a log-linear production function, where the results obtained from the level variables are in the form of elasticities. The model to be estimated is as follows:

$$
\ln V A_{s, a, t}=\alpha+\delta \ln K_{s, a, t}+L_{s, a, t}^{\prime} \pi+S_{a, t}^{\prime} \theta+Z_{s, t}^{\prime} \rho+u_{s, t}+\varepsilon_{s}
$$

\footnotetext{
8 See George (1966), Takeuchi and Bucklin (1980, 1981), Achabal, Heineke, and McIntyre (1984, 1985), Tilley and Hicks (1970), and Ingene $(1982,1984,1985)$.

${ }^{9}$ A Cobb-Douglas production function can be written as follows: $\mathrm{Y}=\mathrm{AK} \mathrm{K}^{\alpha} \mathrm{L}^{\beta}$, which can be rewritten for output per labor (value added per employee) as $\mathrm{Y} / \mathrm{L}=\mathrm{AK} \mathrm{K}^{\alpha} \mathrm{L}^{\beta-1}$. From this form, we can obtain the following linear form to be estimated: $\ln (\mathrm{Y} / \mathrm{L})=\mathrm{a}+\mathrm{b} \ln \mathrm{K}+\mathrm{clnL}$. $($ Observe that $\beta-1=\mathrm{c})$
} 
The goal is to capture the productivity returns to market size. Whereas $V A$ represents the value added per employee in store $S$ in retail market $a$ in year $t, S^{\prime}$ represents the three market size variables (municipal, regional, and external) and the retail LQ, the construction of which is discussed in detail in the previous subsection. The primary goal of the analysis is to capture the effects from the three market size measures to identify the spatial sources of productivity. Achieving this goal requires isolating the effects from individual store characteristics that can be associated with the productivity directly or indirectly. The amount of physical capital (in Swedish crowns) is represented by $K$ controls for the effect from one of the two major production factors. The second major production factor, labor, is then investigated by a vector of variables, denoted by $L^{\prime}$, associated with the number and characteristics of the employees in an individual store. The justification for controlling for the characteristics of employees in a store in addition to the amount of labor used in the production is that the production of labor can be improved not only by changing employee scheduling but also by revising the composition of the labor that is used in the production process. For example, the productivity returns to an extra hour worked by a salesperson may not be equivalent to the returns to an extra hour worked by an employee holding a managerial position. In addition, the demographic characteristics of labor (i.e., female share, immigrant share) may play a significant role. $Z^{\prime}$ represents municipality dummies that are introduced into the analysis to control for heterogeneity across different markets and across different types of retailing activities. Even when we control for several attributes of a store, unobserved characteristics that are intrinsic to these stores (time invariant) may still induce higher productivity. To avoid having possible upward biased estimates for the market size variables, a fixed-effect error term, $u_{s}$, is introduced for the individual stores.

\subsection{Data and variables}

The data that are used in the study are on the establishment level and were obtained from Statistics Sweden for the years between 2002 and 2008. The dataset is a publicly audited dataset containing information on every individual active in the labor market and their workplaces, which can therefore be linked to the firm to which the establishment belongs ${ }^{10}$. The selection of the period is based on the macroeconomic level consistency as well as significant changes in the industrial categorization occurring after 2002. The data initially contain information on all independent stores that have a positive value added. After the exclusion of outliers, the total number of observations is approximately 30,000 (over 81,000 observations for the entire period of seven years) ${ }^{11}$. Approximately 19,000 of these stores were located in central municipalities, and the rest were hosted by peripheral (non-central) municipalities. The descriptive statistics and pairwise correlations can be found in the appendix. Figure 5 displays the variables that are used in the analysis under two main headings: Market size and place in the regional bierarchy and Store

\footnotetext{
${ }^{10}$ Because the capital and value added figures are only available on the firm level, their use is only possible for independent stores where a firm has only one plant (store).

${ }^{11}$ Unbalanced panel.
} 
and employee characteristics. In addition, municipality dummies are used as controls. The variables are defined in detail below.

Market size and place in the regional hierarchy

- Municipal market size: Accessible market size within the municipal borders

- Regional market size: Accessible market size within the region

- External market size: Accessible market size from outside the region

- Retail LQ: The relative concentration of the retail sector in a municipality compared to the country average

- Competition: The relative competitiveness of the retail sector in a municipality compared to the country average

\section{Store and employee characteristics}

- Number of employees: The size of the store in terms of the number of employees

- Capital: Physical capital (in Swedish crowns)

- Female share: Share of female employees

- Manager share: Share of employees with a managerial occupation

- Sales personal share: Share of employees that are assigned to sales related tasks

- HC share: The share of human capital is the share of employees with three or more years of higher education

- Store age: Number of years since the store became active

- Immigrant share: Share of foreign-born employees

Figure 5: Variables used in the empirical analysis

\section{Market size and place in the regional hierarchy}

Because market size constitutes the core of the analysis, the three measures for the accessible market size, together with the retail LQ and Competition, constitute the variables of interest. The three market accessibility measures are municipal market size, regional market size, and external market accessibility. These measures are log transformed in the empirical analysis, along with the value added per employee (which is used as the dependent variable). Hence, the results that are obtained from the regression analyses for these market size variables are elasticities.

Additionally, the LQs and a measure of the competitiveness of the retail sector in the respective municipalities are introduced into the analysis to control for the degree of retail specialization in the market. The $L Q$ captures the relative concentration of the whole retail sector in a municipality in terms of employment. Although the competition variable is very similar to the LQ in terms of its calculation, it captures the relative competitiveness in the retail sector with respect to the national average (Glaeser et al., 1992). This variable is calculated as follows:

$$
\text { Competition }_{r, m}=\left(\frac{s_{r, m}}{e_{r, m}}\right) /\left(\frac{s_{m}}{e_{m}}\right)
$$

where $s$ is the number stores, $e$ is the number of employees, $r$ denotes the retail sector, and $m$ stands for the municipality. A ratio exceeding one implies that there is a relatively more competitive retail milieu in 
the municipality compared to the national average and indicates that there are more establishments (stores) relative to the size of the municipality compared to the rest of the country.

\section{Store and employee characteristics}

The analysis accounts for the productivity related to store size in terms of number of employees and physical capital. The amount of capital and labor are the two fundamental production factors. The impact of labor is captured in terms of the total number of employees in a store. In addition, the capital variable corresponds to physical assets, such as the machines and equipment that are used to handle the goods in a store and to provide the retail service (e.g., vehicles, cash machines, shelves, mannequins, coolers, computers, and sound systems). This variable includes neither immaterial capital (such as stocks and patents) nor floor space because of the inconsistencies in the data source.

In addition to these two variables, another set of variables is introduced to capture the impact of the employee composition in a store. These variables include the share of female employees, the share of firstgeneration immigrant employees, and the share of employees with a minimum of three years of higher education. The analysis also uses two occupation-based variables to account for the variations across different tasks and the effects of the distribution of high-end and low-end occupations on productivity by introducing the share of employees with a managerial position ${ }^{12}$ and the sales personal share.

\subsection{Estimation results}

Table 1 displays the results from a fixed-effect estimation of the independent stores located in central and non-central (peripheral) markets seperately. The primary goal of this estimation is to capture (i) the variation in the size of the impact between the three market size measures and (ii) how these effects vary between central and non-central markets.

The first regressions (regressions 1 and 2) examine the impact of capital and employee characteristics only and do not incorporate the market size measures, LQs, or competition ratios into the model. The estimated coefficients for the variables that capture the impact of the store and employee attributes do not appear to change once the market size variables are introduced ${ }^{13}$, with the exception of store age. The influence of the number of employees on productivity should be interpreted while bearing in mind the original Cobb-Douglas formulation. Because the left hand-side variable is the value added divided by the number of employees, the estimated coefficient that we obtain for the labor variable plus one should give

\footnotetext{
12 Managerial occupations include chief and executive officers and marketing personnel.

13 As can be seen from the pairwise correlations, the size of the stores and the size of the market do not correlate to a great degree. This result, to some extent, implies that large establishments are not necessarily sorted into large markets.
} 
us the actual effect of labor on output levels ${ }^{14}$. Doubling capital is associated with only a 3-4 percent productivity increase, although this impact is slightly stronger for stores that are located in non-central municipalities. Capital appears to play a much less significant role for these independent stores than one would expect; this weak effect may at least partially be due to the lack of data on floor space in the data on physical capital. This lack of information also makes it impractical to make an argument on increasing/decreasing returns to scale based on the estimated coefficients obtained from capital and labor. Additionally, retailers in general are not very dependent on physical capital because they are very labor intensive.

The labor characteristics have an insignificant impact on the productivity of stores located in central markets. However, the manager share and sales personal share are associated with an approximately 5.5 percent productivity increase for independent stores located in non-central municipalities. This result may largely be explained by returning to the division of labor argument. The majority of the independent stores in non-central peripheral markets are run by either one or very few employees. Thus, any change in the decomposition of labor may reflect a greater productivity improvement for non-centrally located stores.

The second set of regressions (regressions 3 and 4) examines the impact of the total accessible market potential, where the three different aggregates are not introduced into the analysis separately. This specification capture the relevant market potential derived from the entire Swedish demand for any store regardless of whether it is located in a central or non-central market. The total accessible market potential is a catch-all variable, as it captures the effects of many scale-related attributes of the markets, where the elasticity is greater than 0.75 for stores in central municipalities and 0.70 for stores in peripheral municipalities. As a result, when the entire market potential for a particular store is doubled, we should see a greater than 70 percent increase in its productivity. Deriving the economic significance of this result from its statistical interpretation is difficult because such a change in the total market potential requires major shifts in both the overall purchasing power and the accessibility in the country as a whole.

When we examine the impact of the three accessible market size measures, the picture is different. Regression 5 is performed for all Swedish municipalities, and regressions 6 and 7 are performed for central and non-central municipalities, respectively, where our variables of interest are introduced into the model. The productivity of independent retailers located in central municipalities appears to be more sensitive to the demand in the immediate market, which is captured by municipal market size, than that of stores located in peripheral markets. For example, doubling the municipal market size is associated with an approximately 30 percent productivity increase for centrally located stores but only an approximately 12 percent for non-centrally located stores. One practical interpretation of this result is that if a store moves from a central municipality to another municipality that is twice as large in terms of municipal market size (e.g., if the store moves from Gothenburg to Stockholm), it can enjoy an approximately 30 percent ${ }^{14} \mathrm{~A}$ robustness check is performed where the variation in value added is estimated against capital and labor, as suggested by the
original Cobb-Douglas function. 
productivity increase, all other factors being held constant. Regarding the impact of regional market size, we find no notable difference between stores located in central markets and stores located in peripheral markets. This parity is in line with the previous discussion, which suggests that shops in the same regional market are in competition for the same set of consumers. In fact, for retailers located in non-central markets, the impact of the regional market is much higher than the impact of the immediate market, which implies that the relevant market boundary for the productivity of non-centrally located stores extends beyond municipal borders. The productivity of non-centrally located stores thus appears to be more dependent on the potential demand in the region than on the potential demand in very close proximity.

The most interesting result most likely pertains to external market size. When the external market size is doubled, stores located in central markets can enjoy an approximately 40 percent productivity increase, whereas stores located in non-central markets enjoy an approximately 50 percent productivity increase. In economic terms, whereas a drastic increase in the municipal market size or regional market size is plausible through either the relocation of a store or a significant improvement in the connectivity (infrastructure) and/or purchasing power in a region, the same type of change cannot be realized as easily for the external market potential.

The estimated coefficients for the retail LQ indicate that sector specialization has a great impact on the productivity levels of independent retailers and that sector specialization plays a more important role for centrally located stores than for their non-centrally located counterparts. The relative competitiveness of local markets with respect to the country average is captured by competition, which appears to have an insignificant impact on productivity in both central and non-central retail markets. Nevertheless, the large coefficients for the market size measures can be reasonably argued to already reflect the impact of the degree of competition in a market.

Table 1: Store productivity (fixed effect estimation results)

\begin{tabular}{|c|c|c|c|c|c|c|c|}
\hline & \multicolumn{2}{|c|}{ Store characteristics } & \multicolumn{2}{|c|}{ Total market potential } & \multicolumn{3}{|c|}{ Market access and regional hierarchy } \\
\hline & \begin{tabular}{|l}
$1]$ \\
Central
\end{tabular} & $\begin{array}{l}{[2]} \\
\text { Non-central }\end{array}$ & $\begin{array}{l}{[3]} \\
\text { Central }\end{array}$ & $\begin{array}{l}{[4]} \\
\text { Non-central }\end{array}$ & $\begin{array}{l}5] \\
\text { All } \\
\end{array}$ & \begin{tabular}{|l|}
$6]$ \\
Central
\end{tabular} & $\begin{array}{l}{[7]} \\
\text { Non-central }\end{array}$ \\
\hline Number of employees & $\begin{array}{l}-0.599 * * * \\
{[0.00689]}\end{array}$ & $\begin{array}{l}-0.643^{* * *} \\
{[0.00759]}\end{array}$ & $\begin{array}{l}-0.599 * * * \\
{[0.00690]}\end{array}$ & $\begin{array}{l}-0.643 * * * \\
{[0.00759]}\end{array}$ & $\begin{array}{l}-0.616^{* * *} \\
{[0.00510]}\end{array}$ & $\begin{array}{l}-0.599 * * * \\
{[0.00690]}\end{array}$ & $\begin{array}{l}-0.643^{* * *} \\
{[0.00759]}\end{array}$ \\
\hline Capital [in SEK] & $\begin{array}{c}0.0337 * * * \\
{[0.00198]}\end{array}$ & $\begin{array}{c}0.0365^{* * *} \\
{[0.00220]}\end{array}$ & $\begin{array}{l}0.0337 * * * \\
0.00981\end{array}$ & $\begin{array}{l}0.0360 * * * \\
0.00857\end{array}$ & $\begin{array}{c}0.0349 * * * \\
{[0.00147]}\end{array}$ & $\begin{array}{l}0.0338^{* * *} \\
{[0.00198]}\end{array}$ & $\begin{array}{c}0.0360^{* * *} \\
{[0.00219]}\end{array}$ \\
\hline Female share & $\begin{array}{c}0.00583 \\
{[0.0152]}\end{array}$ & $\begin{array}{c}0.00753 \\
{[0.0174]}\end{array}$ & $\begin{array}{r}0.00981 \\
{[0.0152]}\end{array}$ & $\begin{array}{r}0.00857 \\
{[0.0173]}\end{array}$ & $\begin{array}{c}0.00845 \\
{[0.0114]}\end{array}$ & $\begin{array}{c}0.0104 \\
{[0.0152]}\end{array}$ & $\begin{array}{c}0.00885 \\
{[0.0173]}\end{array}$ \\
\hline Manager share & {$\left[\begin{array}{l}-0.00361 \\
{[0.0186]}\end{array}\right.$} & $\begin{array}{l}0.0589^{* * *} \\
{[0.0205]}\end{array}$ & $\begin{array}{l}-0.0112 \\
{[0.0186]}\end{array}$ & $\begin{array}{l}0.0565^{* * *} \\
{[0.0205]}\end{array}$ & $\begin{array}{c}0.0176 \\
{[0.0138]}\end{array}$ & $\begin{array}{l}-0.0124 \\
{[0.0186]}\end{array}$ & $\begin{array}{l}0.0558^{* * *} \\
{[0.0205]}\end{array}$ \\
\hline Sales personal share & $\begin{array}{c}0.0145 \\
{[0.0158]}\end{array}$ & $\begin{array}{l}0.0541^{* * *} \\
{[0.0175]}\end{array}$ & $\begin{array}{r}0.00870 \\
{[0.0158]}\end{array}$ & $\begin{array}{l}0.0516^{* * *} \\
{[0.0174]}\end{array}$ & $\begin{array}{c}0.0299^{* *} \\
{[0.0117]}\end{array}$ & $\begin{array}{c}0.00793 \\
{[0.0158]}\end{array}$ & $\begin{array}{l}0.0514^{* * *} \\
{[0.0174]}\end{array}$ \\
\hline HC share & $\begin{array}{l}-0.0130 \\
{[0.00850]}\end{array}$ & $\begin{array}{c}0.0102 \\
{[0.00897]}\end{array}$ & $\begin{array}{l}-0.00958 \\
{[0.00852]}\end{array}$ & $\begin{array}{l}0.0110 \\
{[0.00895]}\end{array}$ & $\begin{array}{l}-0.00151 \\
{[0.00619]}\end{array}$ & $\begin{array}{l}-0.00959 \\
{[0.00851]}\end{array}$ & $\begin{array}{c}0.0112 \\
{[0.00895]}\end{array}$ \\
\hline Store age & $\begin{array}{r}0.0361 * * * \\
{[0.000865}\end{array}$ & $\begin{array}{c}0.0342 * * * \\
{[0.000914]}\end{array}$ & $\begin{array}{c}0.00211 \\
{[0.00313]}\end{array}$ & $\begin{array}{c}0.00292 \\
{[0.00348]}\end{array}$ & $\begin{array}{l}-0.00215 \\
{[0.00275}\end{array}$ & $\begin{array}{l}-0.00179 \\
{[0.00366}\end{array}$ & $\begin{array}{l}-0.00292 \\
{[0.00414]}\end{array}$ \\
\hline Immigrant share & $\begin{array}{c}0.0329 * \\
{[0.0178]}\end{array}$ & $\begin{array}{c}0.00555 \\
{[0.0193]}\end{array}$ & $\begin{array}{c}0.0286 \\
{[0.0179]}\end{array}$ & $\begin{array}{c}0.00176 \\
{[0.0193]}\end{array}$ & $\begin{array}{c}0.0189 \\
{[0.0131]}\end{array}$ & $\begin{array}{c}0.0286 \\
{[0.0179]}\end{array}$ & $\begin{array}{c}0.000443 \\
{[0.0193]}\end{array}$ \\
\hline $\begin{array}{l}\text { LQ_Retail } \\
\text { Competition }\end{array}$ & & & $\begin{array}{c}1.365^{* * *} \\
{[0.339]} \\
0.0531\end{array}$ & $\begin{array}{l}1.184 * * * \\
{[0.255]} \\
-0.0316\end{array}$ & $\begin{array}{c}0.183 \\
{[0.278]} \\
-0.0111\end{array}$ & \begin{tabular}{|c|}
$0.926^{* *}$ \\
{$[0.400]$} \\
0.0412
\end{tabular} & $\begin{array}{l}1.065^{* * *} \\
{[0.253]} \\
-0.0327\end{array}$ \\
\hline
\end{tabular}




\begin{tabular}{|c|c|c|c|c|c|c|c|}
\hline $\begin{array}{l}\text { Total market access } \\
\text { Municipal market size } \\
\text { Regional market size } \\
\text { External market size }\end{array}$ & & & $\begin{array}{c}{[0.0348]} \\
0.772 * * * \\
{[0.0685]}\end{array}$ & $\begin{array}{c}{[0.0201]} \\
0.707 * * * \\
{[0.0757]}\end{array}$ & $\begin{array}{c}{[0.0180]} \\
\\
0.203^{* * *} \\
{[0.0482]} \\
0.225^{* * *} \\
{[0.0435]} \\
0.460^{* * *} \\
{[0.0799]}\end{array}$ & $\begin{array}{c}0.287 * * * \\
{[0.0792]} \\
0.249 * * * \\
{[0.0535]} \\
0.373 * * * \\
{[0.109]}\end{array}$ & $\begin{array}{c}0.115^{*} \\
{[0.0606]} \\
0.255^{* * *} \\
{[0.0947]} \\
0.487^{* * *} \\
{[0.135]}\end{array}$ \\
\hline Constant & $\begin{array}{l}5.858^{* * *} \\
{[0.0793]} \\
\end{array}$ & $\begin{array}{l}5.837 * * * \\
{[0.102]} \\
\end{array}$ & \begin{tabular}{|l}
$-14.84 * * *$ \\
{$[1.881]$} \\
\end{tabular} & $\begin{array}{l}-11.77 * * * \\
{[1.848]}\end{array}$ & \begin{tabular}{|l}
$-13.82^{* * *}$ \\
{$[1.386]$} \\
\end{tabular} & $\begin{array}{l}-15.50^{* * *} \\
{[1.861]}\end{array}$ & $\begin{array}{l}-13.59 * * * \\
{[2.070]}\end{array}$ \\
\hline \begin{tabular}{|l|} 
Observations \\
R-squared \\
Number of stores
\end{tabular} & $\begin{array}{c}46,998 \\
0.249 \\
18,188\end{array}$ & $\begin{array}{c}34,745 \\
0.302 \\
12,819\end{array}$ & \begin{tabular}{|l|}
46,799 \\
0.252 \\
18,130
\end{tabular} & $\begin{array}{l}34,692 \\
0.305 \\
12,797\end{array}$ & \begin{tabular}{|l|}
81,491 \\
0.275 \\
30,573
\end{tabular} & $\begin{array}{l}46,799 \\
0.253 \\
18,130\end{array}$ & $\begin{array}{l}34,692 \\
0.305 \\
12,797\end{array}$ \\
\hline
\end{tabular}

Standard errors are in parentheses, ${ }^{* * *} \mathrm{p}<0.01,{ }^{* *} \mathrm{p}<0.05,{ }^{*} \mathrm{p}<0.1$, and all level variables are log transformed.

\subsubsection{Variations across different types and sizes of stores}

The retail sector consists of highly heterogeneous activities. As these activities are distinct in their location patterns, their response to market size should also vary with regard to productivity returns. A common approach is to use the "durable" vs. "nondurable" dichotomy in the retail literature, which may lead to coarse results because of the ambiguity and heterogeneity of the retail branches that can be nested under the "durable" category. Thus, this paper examines the variations in productivity returns to market size across different types of retailing activities by using four categories ${ }^{15}$ : food, clothing, household, and specialized. Different types of retailing activities are grouped into these four categories with respect to the goods that they provide as well as the commonalities in their location patterns ${ }^{16}$.

The first category, food retailing, is known to be very sensitive to the proximity to demand because the nondurable goods purchased by these stores are not very likely to be carried far away from the location where they are provided. Instead, these goods are likely to be found in city centers close to residential areas or in close proximity to such centers. Purchases of the goods provided by these shops are more frequent than purchases of other commodities provided by the retail market. The second category, clothing, corresponds to a significant share of the retail market. As individual stores, such retailers dominate downtown retail markets, but they can also be found in regional malls and/or in out-of-town retail clusters. The clothing goods are purchased less frequently than food goods but more frequently than large and expensive household items, which places this category somewhere between durable and nondurable goods.

The third retail category, household, involves various retailing activities such as the retail sale of electronic goods, furniture, and construction materials. Because these retailing activities require more store space and because consumers purchase goods provided by these stores less frequently and are willing to travel greater distances to do so, retailers in this category tend to be located farther from the city core. Indeed,

\footnotetext{
${ }^{15} \mathrm{~A}$ detailed list of the retailing activities listed under these four categories can be found in the appendix.

${ }^{16}$ The second chapter of the thesis, which is entitled "Market Reach for Retail Services", addresses the variations in the location patterns of these four retail categories.
} 
these stores are often found at the intersection of different markets and regional hubs, and they are located close enough to a sufficiently large market to secure a certain threshold of demand yet far enough from the core to enjoy lower rent costs. The fourth category, specialized stores, is the most heterogeneous category in terms of the goods and services provided by such stores. Each store is specialized in providing one or a few particular lines of goods, and thus, such stores include opticians, pet stores, flower shops, bookstores, and music shops. Consumers' willingness to travel far in order to patronize these stores is relatively low, so these stores are almost always located in the very core of the market. The physical size of these stores is often small, which allows them to compensate for the high rents in the central parts of local markets.

Table 2 displays the market size elasticities for food, clothing, housebold, and specialized independent retailers separately ${ }^{17}$. No statistically significant productivity return from a larger municipal market size is found for independent food retailers in central markets, whereas their counterparts in non-central markets enjoy a productivity premium with respect to the immediate market size. Regional market size has a positive impact on the productivity of independent food retailers in both central and non-central municipalities, and the impact is higher for non-centrally located stores than for centrally located stores.

For clothing, only independent stores located in central markets experience a productivity return from a larger municipal market size and regional market size; the magnitude of the impact of these two market size measures is similar (the elasticity is approximately 0.35 ). This result is consistent with the argument that the nature of the demand that is associated with a large market potential may allow retailers to specialize in niche products and services and to exploit the demand from a certain segment of consumers. (For example, one can think of an independent shop providing customized clothing, thus, charging higher prices for its premium good in a large market.) Independent household retailers have a notable productivity premium with respect to the municipal market size, where the impact is approximately 0.5 in central municipalities and 0.3 in non-central municipalities. However, regional market size appears to have an insignificant relationship with the productivity levels of independent household retailers. One may argue that this result would be the opposite for chain household retailers, where the relevant market boundary should reasonably extend beyond the municipal borders. In that case, this interesting result may indicate that markets may be shared by chain and independent stores that provide high-order goods in a different manner. For the productivity of independent household retailers, the critical factor is revealed to be the immediate market potential rather than the regional market size.

The productivity of the independent specialized stores is found to be highly associated with all three market size measures for stores located in central markets. For stores located in non-central markets, municipal market size does not have a significant impact, whereas regional market size and external market size are strongly associated with stores' productivity. The lack of significance of the immediate market size (i.e., the municipal market size) for specialized retailers located in non-central markets can be explained by the

\footnotetext{
17 The full model is estimated, but only the results for the market size variables are reported.
} 
argument proffered previously: to provide a niche retailing service, the market must be sufficiently large. Thus, for most of these stores, the relevant market size for a productivity return can be reasonably assumed to extend beyond the borders of the municipality in which they are located.

An overall conclusion from the results is that the competition between markets (especially those located in the same region) has no negative impact on the productivity of independent retailers. The impact of all three market size variables is either insignificant or positive in all cases.

Table 2: Elasticities for different retailing activities

\begin{tabular}{|l|cl|cc|cc|cc|}
\hline & \multicolumn{2}{|c|}{ FOOD } & \multicolumn{2}{c|}{ CLOTHING } & \multicolumn{2}{c|}{ HOUSEHOLD } & \multicolumn{2}{c|}{ SPECIALIZED } \\
\hline VARIABLES & Central & Non-central & Central & Non-central & Central & Non-central & Central & Non-central \\
\hline Municipal market size & 0.0925 & $0.284^{* * *}$ & $0.370^{*}$ & -0.0403 & $0.484^{* * *}$ & $0.311^{* *}$ & $0.297^{* *}$ & -0.0121 \\
& {$[0.138]$} & {$[0.105]$} & {$[0.222]$} & {$[0.198]$} & {$[0.182]$} & {$[0.128]$} & {$[0.148]$} & {$[0.111]$} \\
\multirow{4}{*}{ Regional market size } & $0.363^{* * *}$ & $0.488^{* * *}$ & $0.322^{* *}$ & 0.318 & -0.0209 & 0.0524 & $0.360^{* * *}$ & $0.302^{*}$ \\
& {$[0.0911]$} & {$[0.172]$} & {$[0.155]$} & {$[0.289]$} & {$[0.114]$} & {$[0.191]$} & {$[0.105]$} & {$[0.178]$} \\
External market size & $0.620^{* * *}$ & $0.540^{* *}$ & -0.127 & 0.0514 & 0.296 & 0.240 & $0.340^{*}$ & $0.552^{* *}$ \\
& {$[0.193]$} & {$[0.238]$} & {$[0.307]$} & {$[0.410]$} & {$[0.246]$} & {$[0.275]$} & {$[0.204]$} & {$[0.254]$} \\
\hline Observations & 9,677 & 8,452 & 7,407 & 4,643 & 9,168 & 7,592 & 13,518 & 9,508 \\
R-squared & 0.339 & 0.348 & 0.248 & 0.305 & 0.213 & 0.270 & 0.260 & 0.357 \\
Number of Stores & 3,895 & 3,077 & 3,156 & 1,839 & 3,269 & 2,561 & 5,008 & 3,465 \\
\hline
\end{tabular}

The retail sector is highly heterogeneous in terms of not only the types of goods and services that stores provide but also the size of stores. With size being measured in terms of the number of employees, approximately 50 percent of all independent stores have fewer than five employees, and approximately 90 percent of these stores have fewer than 15 employees. Only approximately half a percent of these stores operate at a scale that enable them to employ more than 75 employees. The variation in the productivity returns to market size across these different store sizes are shown in Table 3, where these independent stores are grouped under three categories.

Overall, we see that small stores (1-5 employees) in central markets and large stores (15 employees or more) in non-central markets are the only retailers that benefit from the scale of the municipal market. The relation between regional market size and productivity appears to be consistent with the previous results, with a slightly higher premium for large stores with 15 employees or more than for small and medium-sized stores. In contrast, the external market size does not have a significant effect on these large stores, whereas for small and medium-sized independent stores, its importance appears to be very large (the elasticities vary between 0.33 and 0.54 ).

Table 3: Elasticities for different store sizes

\begin{tabular}{|c|c|c|c|c|c|c|}
\hline & \multicolumn{2}{|c|}{ 1-5 employees } & \multicolumn{2}{|c|}{ 6-15 employees } & \multicolumn{2}{|c|}{15 employees or more } \\
\hline & Central & Non-central & Central & Non-central & Central & Non-central \\
\hline \multirow{2}{*}{ Municipal market size } & $0.323^{* * *}$ & -0.000546 & 0.119 & -0.000546 & 0.164 & $0.373^{* * *}$ \\
\hline & {$[0.117]$} & {$[0.0872]$} & {$[0.143]$} & {$[0.0872]$} & {$[0.194]$} & {$[0.139]$} \\
\hline \multirow{2}{*}{ Regional market size } & $0.270^{* * *}$ & $0.283^{* *}$ & 0.124 & $0.283^{* *}$ & $0.321 * *$ & $0.369^{*}$ \\
\hline & [0.0811] & [0.139] & {$[0.0926]$} & {$[0.139]$} & [0.139] & {$[0.213]$} \\
\hline External market size & $0.523^{* * *}$ & $0.533^{* * *}$ & $0.329 *$ & $0.533^{* * *}$ & -0.0319 & 0.0691 \\
\hline
\end{tabular}




\begin{tabular}{|l|ll|ll|ll|} 
& {$[0.164]$} & {$[0.197]$} & {$[0.187]$} & {$[0.197]$} & {$[0.269]$} & {$[0.308]$} \\
\hline Observations & 29,044 & 22,592 & 10,278 & 22,592 & 4,095 & 3,014 \\
R-squared & 0.272 & 0.324 & 0.187 & 0.324 & 0.156 & 0.188 \\
Number of stores & 12,901 & 9,481 & 4,324 & 9,481 & 1,355 & 880 \\
\hline
\end{tabular}

\section{Concluding remarks}

This paper addresses the productivity returns to market size and the relevance of the centrality of a retail market for the productivity of independent retailers. In particular, three different measures of market size are used to capture the market size in municipalities, region and areas outside the regions under study. In this way, the analysis allows for a discussion of the relevance of the spatial continuum of demand. The study focuses on the importance of the urban-periphery dichotomy for independent retailers' productivity, and hence, the productivity returns to market size are expected to vary across stores located in central and non-central markets. The paper also examines the possible effects from store and employee characteristics and aims to capture the variations across independent retailers of different types and sizes.

The findings suggest that the market size in close proximity has a higher impact on the productivity of stores located in central municipalities, whereas the market potential in the region appears to have similar productivity returns for both stores in central markets and stores in non-central markets. No significant productivity impact from employee characteristics is captured for stores located in central markets, whereas stores located in non-central municipalities can be argued to receive a return to the division of labor. For these non-centrally located stores, the share of managers and sales personnel has a small but significant impact on their productivity levels. When we examine the variation in the relationship between market size and productivity across different types of retailing activities, the productivity of stores selling nondurable goods in non-central markets is found to be dependent on the market size within close proximity, whereas no such impact is evident for stores that are located in central municipalities. The relationship between market size and productivity is found to vary for stores selling durable goods. Large, specialized stores in central markets enjoy productivity returns to market size both in close proximity and in the region, whereas for non-centrally located stores, the relevant market boundary for the market sizeproductivity relationship appears to extend beyond the municipal market. With stores selling high-order goods for less frequent purchases, only the productivity return to the market size in close proximity is large, and this effect is even larger for centrally located retail establishments. In addition, small stores in central markets and large stores in non-central markets are found to have productivity returns to the market size in close proximity.

The theoretical background of this study suggests that when we examine the relationship between market size and productivity, absolute size is not the only factor that is important. From a regional economics viewpoint, exclusively considering the impact of the immediate market is insufficient. The results of this study show that the regional and external market potential also matters, and even to a greater extent than 
the market in close proximity for productivity of certain types of independent retailers. The findings also suggest that whether the centrality of the market where a store is located plays a role in explaining the impact of market size on independent retailers' productivity.

The paper faces the limitation of not decomposing the substance of market potential while examining the productivity effects from the market potential. As the empirical analysis stands, no distinction is drawn between the benefits that arise from agglomerative forces (e.g., learning, sharing, and matching) and the benefits that are purely associated with the size of demand. Nevertheless, this paper outlines a framework for future studies to scrutinize the possible implications of the centrality of store location, as well as the importance of demand at different distances for productivity. This type of analysis is useful not only for sector actors in determining the optimum location conditions for higher productivity returns to market size, but also for policy makers for investing in infrastructure to improve the connectivity between markets in the same region or facilitating retail agglomeration through deregulations.

\section{References}

Abdel-Rahman, H., \& Fujita, M. (1990). Product Variety, Marshallian Externalities, and City Sizes. Journal of Regional Science, 30(2), 165-183.

Achabal, D., Heineke, J., \& McIntyre, S. (1984). Issues and perspectives on retail productivity. Journal of Retailing, 60(3), 107-129.

Achabal, D., Heineke, J., \& McIntyre, S. H. (1985). Productivity measurement and the output of retailing. Journal of retailing, 61(3), 83-88.

Andersson, M., \& Gråsjö, U. (2009). Spatial dependence and the representation of space in empirical models. The annals of regional science, 43(1), 159-180.

Andersson, M., \& Klaesson, J. (2009). Regional interaction and economic diversity: exploring the role of geographically overlapping markets for a municipality's diversity in retail and durables. Innovation, Agglomeration and Regional Competition, 19-37.

Applebaum, W., \& Green, H. L. (1974). Determining store trade areas.Handbook of marketing research, 4-313.

Beckmann, M. J. (1958). City hierarchies and the distribution of city size. Economic Development and Cultural Change, 6(3), 243-248.

Beckmann, M. J. (1999). Lectures on location theory. Springer.

Berry, B. J. L. (1967). Geography of Marketing Centers and Retail Distribution. New Jersey, Prentice-Hall.

Berry, B. J. L. and W. L. Garrison (1958a). "Recent Developments of central place theory." Proceedings of the Regional Science Association 4: 107.

Berry, B. J. L. and W. L. Garrison (1958b). "A note on central place theory." Economic Geography 34: 304-311. 
Birkin, M., Clarke, G., \& Clarke, M. P. (2002). Retail geography and intelligent network planning. Wiley.

Bound, J., \& Johnson, G. E. (1989). Changes in the Structure of Wages during the 1980's: An Evaluation of Alternative Explanations (No. w2983). National Bureau of Economic Research.

Bucklin, L. P. (1980). Retail Productivity Measurement Methods and Performance Trends. In Productivity in General Merchandise Retailing, Stanton G. Cort (ed.), New York: National Retail Merchants Association, 23-32.

Bucklin, L. P. (1981). Growth and Productivity Change in Retail. In Theory in Retailing. Traditional and Nontraditional Sources, Ronald W. Stampfl and Elizabeth C Hirschman (eds.), Chicago, American Marketing Association, 21-33.

Christaller, W. (1933). Die zentralen Orte in Süddeutschland, Jena: Gustav Fisher.

Clark, W. A. V. (1968). Consumer Travel Patterns and the Concept of Range. Annals of the Association of American Geographers,58(2), 386-396.

Coles, M. G., \& Smith, E. (1998). Marketplaces and matching. International Economic Review, 239-254.

Converse, P. D. (1949). New laws of retail gravitation. The Journal of Marketing,14(3), 379-384.

Costa, D. L., \& Kahn, M. E. (2000). Power couples: changes in the locational choice of the college educated, 1940-1990. The Quarterly Journal of Economics, 115(4), 1287-1315.

Craig, C. S., Ghosh, A., \& McLafferty, S. (1984). Models of the retail location process: a review. Journal of Retailing, 60(1), 5-36.

Denike, K. G., \& Parr, J. B. (1970a). Production in space, spatial competition, and restricted entry. Journal of Regional Science, 10(1), 49-64.

Dicken, P., \& Lloyd, P. E. (1990). Location in space: Theoretical perspectives in economic geography. New York: Harper \& Row.

Doutt, J. T. (1984). Comparative productivity performance in fast-food retail distribution. Journal of Retailing, 60(3), 98-106.

Duranton, G., \& Puga, D. (2001). Nursery cities: Urban diversity, process innovation, and the life cycle of products. American Economic Review, 1454-1477.

Duranton, G., \& Puga, D. (2004). Micro-foundations of urban agglomeration economies. Handbook of regional and urban economics, 4, 2063-2117.

Ellison, Glenn, Edward L. Glaeser, and William R. Kerr. 2010. "What Causes Industry Agglomeration? Evidence from Coagglomeration Patterns." American Economic Review, 100(3): 1195-1213.

Fujita, M., \& Thisse, J. F. (2002). Economies of Agglomeration, Cities, Industrial Location and Regional Growth. Cambridge: CambridgeUniversityPress.

Fujita, M., Krugman, P., \& Mori, T. (1999). On the evolution of hierarchical urban systems. European Economic Review, 43(2), 209-251.

George, K. D. (1966). Productivity in distribution. Cambridge: Cambridge University Press.

Glaeser, E. L. (1999). Learning in cities. Journal of urban Economics, 46(2), 254-277.

Glaeser, E. L., Kallal, H. D., Scheinkman, J. A., \& Shleifer, A. (1992). Growth in Cities. Journal of Political Economy, 100(6), 1126-52.

Glaeser, E. L., Kolko, J., \& Saiz, A. (2001). Consumer city. Journal of economic geography, 1(1), 27-50. 
Golledge, R. G., Rushton, G., \& Clark, W. A. (1966). Some spatial characteristics of Iowa's dispersed farm population and their implications for the grouping of central place functions. Economic Geography, 261-272.

Haig, R. M. (1927). Regional Survey of New York and its Environs.

Hall, M., Knapp, J., and Winsten, C. (1961). Distribution in Great Britain and North America, Oxford University Press, London.

Hanson, G. H. (2001). Scale economies and the geographic concentration of industry. Journal of Economic Geography, 1(3), 255-276.

Haynes, K. E., \& Fotheringham, A. S. (1984). Gravity and spatial interaction models (Vol. 2). Beverly Hills: Sage publications.

Helsley, R. W., \& Strange, W. C. (1990). Matching and agglomeration economies in a system of cities. Regional Science and Urban Economics,20(2), 189-212.

Huff, D. L. (1964). Defining and estimating a trading area. The Journal of Marketing, 34-38.

Ingene, C. A. (1982). Labor productivity in retailing. The Journal of Marketing, 75-90.

Ingene, C. A. (1984). Scale economies in American retailing: a cross-industry comparison. Journal of Macromarketing, 4(2), 49-63.

Ingene, Charles A. (1984). "Productivity and Functional Shifting in Spatial Retailing: Private and Social Perspectives, Journal of Retailing, 60 (Fall): 15-36.

Ingene, C. A. (1985). Labor productivity in retailing: what do we know and how do we know it?. Journal of Marketing, 49(4).

Jacobs, J. The economy of cities, 1969. Vintage, New York.

Johansson, B., \& Karlsson, C. (2001). Geographie Transaction Costs and Specialisation Opportunities of Small and Medium-Sized Regions: Scale Economies and Market Extension. In Theories of Endogenous Regional Growth(pp. 150-180). Springer Berlin Heidelberg.

Johansson, B., \& Klaesson, J. (2007). Infrastructure, labour market accessibility and economic development. The Management and Measurement of Infrastructure-Performance, efficiency and innovation, Edward Elgar, Cheltenham, 69-98.

Johansson, B., \& Klaesson, J. (2011). Agglomeration dynamics of business services. The annals of regional science, 47(2), 373-391.

Johansson, B., Klaesson, J., \& Olsson, M. (2002). Time distances and labor market integration. Papers in Regional Science, 81(3), 305-327.

Johnston, A., Porter, D., Cobbold, T., \& Dolamore, R. (2000). Productivity in Australia's wholesale and retail trade.

Johnston, R. J. (1973). Spatial Structures.

Johnston, R. J., \& Rimmer, P. J. (1967). A Note on Consumer Behaviour in an Urban Hierarchy. Journal of Regional Science, 7(2), 161-166.

Klaesson, J., Larsson, J.P., Norman, T., (2014). Accessibility and Market Potential Analysis. In C. Karlsson, M. Andersson, \& T. Norman (Eds.), Handbook of Research Methods and Applications in Economic Geography (forthcoming). U.K.: Edward Elgar. 
Krugman P.R. (1991) Geography and trade. MIT University Press, Cambridge, MA.

Krugman, P. (1990). Increasing returns and economic geography (No. w3275). National Bureau of Economic Research.

Lakshmanan, J. R., \& Hansen, W. G. (1965). A retail market potential model. Journal of the American Institute of planners, 31(2), 134-143.

Larsson, J. P. \& Öner, Ö., (2014). Location and Co-location in Retail-A Probabilistic Approach Using Geo-coded Data for Metropolitan Retail Markets, The Annals of Regional Science, forthcoming.

Larsson, J. P. (2014). The neighborhood or the region? Reassessing the density-wage relationship using geocoded data. The Annals of Regional Science, forthcoming.

Lusch, R. F., \& Ingene, C. A. (1979). The predictive validity of alternative measures of inputs and outputs in retail production functions. In Proceedings of the 1979 Educators' Conference (pp. 330-333).

Lösch, A. (1940). Die Räumliche Ordnung der Wirtschaft, Gustav Fischer, Jena. English translation (1954): The Economics of location. New Haven, Yale University Press, Connecticut

Marshall, A. (1890). Principles of Economics, 8th ed., Macmillan, London

Ohlin, B. G. (1933). Interregional and international trade. Cambridge, MA: Harvard University Press.

O'Kelly, M. E. (1981). A model of the demand for retail facilities, incorporating multistop, multipurpose trips. Geographical Analysis, 13(2), 134-148.

O'Kelly, M. E. (1983). Impacts of multistop, multipurpose trips on retail distributions. Urban Geography, 4(2), 173-190.

Parr, J. B., \& Denike, K. G. (1970b). Theoretical problems in central place analysis. Economic Geography, $568-586$.

Puga, D. (2010). The Magnitude and Causes of Agglomeration Economies. Journal of Regional Science, 50(1), 203-219.

Ratchford, B. T., \& Brown, J. R. (1985). A study of productivity changes in food retailing. Marketing Science, 4(4), 292-311.

Reilly, W.J. 1929. Methods for the Study of Retail Relationship. University of Texas Bulletin.

Reynolds, J., Howard, E., Dragun, D., Rosewell, B., \& Ormerod, P. (2005). Assessing the productivity of the UK retail sector. The International Review of Retail, Distribution and Consumer Research, 15(3), 237-280.

Rosenthal, S. S., \& Strange, W. C. (2001). The determinants of agglomeration.Journal of Urban Economics, 50(2), 191-229.

Rosenthal, Stuart S. and William C. Strange. 2003. Geography, industrial organization, and agglomeration. Review of Economics and Statistics 85(2):377-393.

Scotchmer, S. (2002). Local public goods and clubs. In Alan J. Auerbach and Martin Feldstein (eds.) Handbook of Public Economics, volume 4. Amsterdam: North-Holland, 1997-2042.

Scott, P. (1970). Geography and Retailing. Hutchinson, London.

Smith, A. (1937). The Wealth of Nations (1776). New York: Modern Library,740. 
Takeuchi, H., \& Bucklin, L. P. (1977). Productivity in Retailing - Retail Structure and Public-Policy. Journal of Retailing, 53(1), 35.

Thill, J. C., \& Thomas, I. (1987). Toward Conceptualizing Trip-Chaining Behavior: A Review. Geographical Analysis, 19(1), 1-17.

Tilley, R. P. R., \& Hicks, R. (1970). Economies of scale in supermarkets. The Journal of Industrial Economics, $1-5$.

\section{Appendix 1}

Table A-1: Descriptive statistics (for central and non-central municipalities)

\begin{tabular}{|c|c|c|c|c|c|}
\hline Variable & Obs & Mean & Std. deviations & Min & Max \\
\hline \multicolumn{6}{|l|}{ ALL municipalities } \\
\hline VA per employee & 88107 & 5.64 & 0.508 & 4.001 & 8.928 \\
\hline Municipal ms & 88046 & 22.48 & 1.560 & 18.637 & 25.659 \\
\hline Regional ms & 88046 & 21.01 & 5.561 & 0.000 & 25.731 \\
\hline External ms & 88046 & 21.08 & 1.259 & 11.383 & 23.283 \\
\hline Retail LQ & 88054 & 1.03 & 0.317 & 0.343 & 3.374 \\
\hline Competition & 87900 & 1.07 & 0.237 & 0.231 & 2.642 \\
\hline Female share & 88107 & 0.40 & 0.290 & 0 & 1 \\
\hline Manager share & 88107 & 0.11 & 0.203 & 0 & 1 \\
\hline Sales p. share & 88107 & 0.43 & 0.293 & 0 & 1 \\
\hline HC share & 88107 & 0.50 & 0.376 & 0 & 1 \\
\hline Store age & 88107 & 7.20 & 6.766 & 0 & 22 \\
\hline Immigrant share & 88107 & 0.65 & 0.228 & 0.067 & 1 \\
\hline Number of emp. & 88107 & 1.49 & 0.855 & 0 & 5.981 \\
\hline Capital & 81800 & 11.74 & 1.942 & 0 & 19.542 \\
\hline \multicolumn{6}{|c|}{ Central municipalities } \\
\hline VA per employee & 50747 & 5.64 & 0.512 & 4.001 & 8.928 \\
\hline Municipal ms & 50747 & 23.28 & 1.467 & 19.066 & 25.659 \\
\hline Regional ms & 50747 & 19.69 & 6.917 & 0.000 & 24.477 \\
\hline External ms & 50747 & 21.02 & 1.502 & 11.383 & 23.142 \\
\hline Retail LQ & 50747 & 1.03 & 0.181 & 0.586 & 2.633 \\
\hline Competition & 50540 & 1.02 & 0.180 & 0.231 & 2.268 \\
\hline Female share & 50747 & 0.39 & 0.293 & 0 & 1 \\
\hline Manager share & 50747 & 0.11 & 0.203 & 0 & 1 \\
\hline Sales p. share & 50747 & 0.44 & 0.294 & 0 & 1 \\
\hline HC share & 50747 & 0.52 & 0.373 & 0 & 1 \\
\hline Store age & 50747 & 6.93 & 6.672 & 0 & 22 \\
\hline Immigrant share & 50747 & 0.66 & 0.228 & 0.067 & 1 \\
\hline Number of emp. & 50747 & 1.51 & 0.847 & 0 & 5.680 \\
\hline Capital & 46998 & 11.67 & 1.917 & 0 & 19.542 \\
\hline \multicolumn{6}{|c|}{ Non-central municipalities } \\
\hline VA per employee & 37299 & 5.63 & 0.502 & 4.001 & 8.790 \\
\hline Municipal ms & 37299 & 21.41 & 0.898 & 18.637 & 23.799 \\
\hline Regional ms & 37299 & 22.81 & 1.523 & 17.087 & 25.731 \\
\hline External ms & 37299 & 21.16 & 0.812 & 18.383 & 23.283 \\
\hline Retail LQ & 37246 & 1.03 & 0.439 & 0.343 & 3.374 \\
\hline Competition & 37299 & 1.15 & 0.281 & 0.402 & 2.642 \\
\hline Female share & 37299 & 0.40 & 0.287 & 0 & 1 \\
\hline Manager share & 37299 & 0.11 & 0.203 & 0 & 1 \\
\hline Sales p. share & 37299 & 0.43 & 0.291 & 0 & 1 \\
\hline HC share & 37299 & 0.47 & 0.379 & 0 & 1 \\
\hline Store age & 37299 & 7.58 & 6.876 & 0 & 22 \\
\hline Immigrant share & 37299 & 0.64 & 0.229 & 0.091 & 1 \\
\hline Number of emp. & 37299 & 1.47 & 0.865 & 0 & 5.981 \\
\hline Capital & 34745 & 11.82 & 1.972 & 0 & 17.683 \\
\hline
\end{tabular}

Log transformed variables: VA per employee, Municipal ms, Regional ms, External ms, Number of emp., and Capital (ms denotes the market size) 


\section{Appendix 2}

Table A-2: Pairwise correlations

\begin{tabular}{|c|c|c|c|c|c|c|c|c|c|c|c|c|c|c|}
\hline & $\begin{array}{c}\text { VA per } \\
\text { emplovee }\end{array}$ & $\begin{array}{c}\text { Municipal } \\
\mathrm{ms}\end{array}$ & $\begin{array}{c}\text { Regional } \\
\text { ms }\end{array}$ & $\begin{array}{c}\text { External } \\
\text { ms }\end{array}$ & $\begin{array}{c}\text { Retail } \\
\text { LQ }\end{array}$ & Competition & $\begin{array}{c}\text { Female } \\
\text { share }\end{array}$ & $\begin{array}{c}\text { Manager } \\
\text { share }\end{array}$ & $\begin{array}{c}\text { Sales p. } \\
\text { share }\end{array}$ & $\begin{array}{l}\mathrm{HC} \\
\text { share }\end{array}$ & Store age & $\begin{array}{c}\text { Immigrant } \\
\text { share }\end{array}$ & $\begin{array}{c}\text { Number of } \\
\text { emp. }\end{array}$ & Capital \\
\hline $\begin{array}{l}\text { VA per } \\
\text { employee }\end{array}$ & 1 & & & & & & & & & & & & & \\
\hline Municipal ms & 0.041 & 1 & & & & & & & & & & & & \\
\hline Regional ms & 0.021 & 0.277 & 1 & & & & & & & & & & & \\
\hline External ms & 0.005 & 0.094 & 0.379 & 1 & & & & & & & & & & \\
\hline Retail LQ & 0.038 & 0.007 & 0.013 & 0.000 & 1 & & & & & & & & & \\
\hline Competition & -0.042 & -0.586 & -0.282 & -0.174 & -0.456 & 1 & & & & & & & & \\
\hline Female share & -0.135 & -0.031 & -0.017 & 0.010 & -0.017 & 0.040 & 1 & & & & & & & \\
\hline Manager share & 0.116 & 0.062 & 0.037 & 0.010 & 0.023 & -0.050 & 0.048 & 1 & & & & & & \\
\hline Sales p. share & -0.011 & 0.025 & -0.004 & -0.008 & -0.017 & 0.005 & 0.447 & -0.369 & 1 & & & & & \\
\hline HC share & 0.019 & 0.143 & 0.058 & 0.016 & 0.026 & -0.098 & 0.029 & 0.028 & 0.032 & 1 & & & & \\
\hline Store age & 0.157 & -0.131 & -0.046 & 0.021 & -0.057 & 0.107 & -0.077 & -0.046 & -0.020 & -0.150 & 1 & & & \\
\hline Immigrant share & 0.131 & 0.101 & 0.045 & -0.002 & 0.001 & -0.055 & 0.386 & 0.297 & 0.462 & 0.049 & -0.098 & 1 & & \\
\hline Number of emp. & 0.082 & 0.044 & 0.022 & 0.019 & 0.041 & -0.095 & 0.000 & -0.027 & 0.038 & 0.054 & 0.181 & -0.077 & 1 & \\
\hline Capital & 0.249 & -0.059 & -0.021 & -0.011 & 0.027 & 0.006 & -0.047 & 0.038 & 0.001 & 0.030 & 0.060 & 0.028 & 0.543 & 1 \\
\hline
\end{tabular}

ms denotes "market size", and $s$ denotes "share". 


\section{Appendix 3}

Table A-3: Retail categories

\begin{tabular}{|c|c|c|}
\hline 5-digit SNI & Description & Type \\
\hline 52111 & Retail sale in department stores and the like, with food, beverages, and tobacco predominating & Food \\
\hline 52112 & Retail sale in other non-specialized stores, with food, beverages, and tobacco predominating & Food \\
\hline 52210 & Retail sale of fruit and vegetables & Food \\
\hline 52220 & Retail sale of meat and meat products & Food \\
\hline 52230 & Retail sale of fish, crustaceans, and mollusks & Food \\
\hline 52241 & Retail sale of bread, cakes, and flour confectionery & Food \\
\hline 52242 & Retail sale of sugar confectionery & Food \\
\hline 52279 & Retail sale of food in specialized stores n.e.c. & Food \\
\hline 52410 & Retail sale of textiles & Clothing \\
\hline 52421 & Retail sale of men's, women's, and children's clothing, mixed & Clothing \\
\hline 52422 & Retail sale of men's clothing & Clothing \\
\hline 52423 & Retail sale of women's clothing & Clothing \\
\hline 52424 & Retail sale of children's clothing & Clothing \\
\hline 52425 & Retail sale of furs & Clothing \\
\hline 52431 & Retail sale of footwear & Clothing \\
\hline 52432 & Retail sale of leather goods & Clothing \\
\hline 52441 & Retail sale of furniture & Household \\
\hline 52442 & Retail sale of home furnishing textiles & Household \\
\hline 52443 & Retail sale of glassware, china, and kitchenware & Household \\
\hline 52443 & Retail sale of lighting equipment & Household \\
\hline 52451 & Retail sale of electrical household appliances & Household \\
\hline 52452 & Retail sale of radio and television sets & Household \\
\hline 52461 & Retail sale of hardware, plumbing, and building materials & Household \\
\hline 52495 & Retail sale of wallpaper, carpets, rugs, and floor coverings & Household \\
\hline 52462 & Retail sale of paint & Household \\
\hline 52471 & Retail sale of books and stationery & Specialized \\
\hline 52472 & Retail sale of newspapers and magazines & Specialized \\
\hline 52481 & Retail sale of spectacles and other optical goods & Specialized \\
\hline 52482 & Retail sale of photographic equipment and related services & Specialized \\
\hline 52483 & Retail sale of watches and clocks & Specialized \\
\hline 52484 & Retail sale of jewelry, gold, and silverware & Specialized \\
\hline 52485 & Retail sale of sports and leisure goods & Specialized \\
\hline 52486 & Retail sale of games and toys & Specialized \\
\hline 52487 & Retail sale of flowers and other plants & Specialized \\
\hline 52488 & Retail sale of pets & Specialized \\
\hline 52491 & Retail sale of art; art gallery activities & Specialized \\
\hline 52492 & Retail sale of coins and stamps & Specialized \\
\hline 52493 & Retail sale of computers, office machinery, and computer programs & Specialized \\
\hline 52494 & Retail sale of telecommunication equipment & Specialized \\
\hline 52453 & Retail sale of gramophone records, tapes, CDs, DVDs, and video tapes & Specialized \\
\hline 52454 & Retail sale of musical instruments and music scores & Specialized \\
\hline
\end{tabular}

